\title{
STUDI PREFERENSI GENERASI Y DALAM MEMILIH HUNIAN DI JAKARTA BARAT
}

\author{
Elzsa Nadiya ${ }^{1}$ \\ ${ }^{1}$ Mahasiswa Magister Teknik Perencanaan, Universitas Tarumanagara, Jakarta \\ echa.nadiya@gmail.com
}

\begin{abstract}
ABSTRAK
Gen Y mendominasi demografi yang ada dengan jumlah populasi tertinggi dan dari life cycle pada posisi early adulthood dan midlife terlihat Gen Y mulai memasuki tahap akan memulai hidup baru seperti memasuki dunia kerja dan berkeluarga, mereka mulai mencari hunian bagi kehidupan baru mereka. Dengan populasi yang begitu besar mencari hunian, tentunya memberikan pengaruh signifikan terhadap pasar hunian, preferensi Gen $Y$ dalam memilih hunian menjadi sangat penting.Masing-masing generasi memiliki karakteristik yang berbeda akibat masa kehidupan yang mereka jalani berbeda, karakteristik Gen $Y$ yang dibesarkan oleh Gen X dan pengaruh perkembangan teknologi yang begitu pesat pada masa kehidupannya, hal tersebut mempengaruhi preferensi Gen $Y$ yang terkait dengan pasar properti baik produk maupun cara pemasaannya. Metode yang digunakan pada penelitian ini adalah metode kuantitatif. Penelitian ini membatasi lingkup penelitian untuk wilayah Jakarta Barat.Mempelajari preferensi Gen $Y$ dalam memilih hunian memberikan manfaat berupa ketersediaan produk properti yang tepat sasaran sehingga dapat memberikan hasil yang optimal baik bagi pengembang dalam menghasilkan produk properti maupun bagi Gen Y itu sendiri dalam memenuhi kebutuhkan hunian dan menjalani kehidupannya. Secara keseluruhan, preferensi Gen Y di Jakarta Barat adalah memilik hunain landed houses, namun keterbatan lahan di Jakarta Barat tidak memungkinkan hal tersebut, Gen Y harus beradaptasi untuk dapat tinggal di hunian vertikal. Mengetahui preferensi Gen Y terkait lokasi hunian sangat bermanfaat untuk pihak pengembang dalam mempersiapkan landbank, terjadi kecenderungan untuk tetap tinggal di pusat kota yaitu di kecamatan Grogol Petamburan, namun ada juga kecenderungan untuk pindah ke daerah suburban yaitu di daerah Serpong dan Tangerang.
\end{abstract}

Kata kunci: Preferensi, Gen Y, Hunian

\section{PENDAHULUAN}

Manusia sebagai makhluk hidup memiliki berbagai macam kebutuhan, beberapa kebutuhan tentu lebih utama dibandingkan kebutuhan lainnya. Menurut Maslow (1954) dalam memenuhi kebutuhan, manusia harus memenuhi kebutuhan di tingkat yang lebih rendah terlebih dahulu atau paling tidak cukup terpenuhi untuk dapat memenuhi kebutuhan di tingkat yang lebih tinggi. Salah satu kebutuhan mendasar (fisiologis) adalah kebutuhan untuk memiliki tempat tinggal. Hunian menjadi salah satu hal penting dalam kehidupan kita sebagai manusia. Dijelaskan oleh Maslow seseorang tidak akan bergerak dengan baik pada tahap aktualisasi diri karena kendala yang didapat pada tingkatan-tingkatan kebutuhan dibawahnya.

Setiap individu manusia memiliki cara yang berbeda-beda dalam memenuhi kebutuhannya, zaman tertentu mempengaruhi karakteristik masing-masing individu dari generasinya. Generasi memiliki kesamaan pada perilaku mereka yang dapat dijadikan gambaran umum. Salah satu generasi yang mencolok karena keberagamannya adalah Generasi Y. (Solomon, 2009). Lingkup generasi ini merupakan manusia kelahiran tahun 1977 hingga tahun 1994 (Hawkins dan Mothersbaugh, 2010).

Setiap generasi memiliki ciri khas masing-masing dan memiliki kriteria yang berbeda dalam pemenuhan kebutuhan dan keinginannya. Karena itu penelitian terhadap preferensi Generasi y dalam memilih hunian menjadi hal yang penting untuk berbagai pihak baik pemerintah maupun pengembang. Pembangunan akan tepat sasaran, dapat dikendalikan pemerintah, dan juga keinginan konsumen terpenuhi dengan baik. 
Tujuan dari penelitian ini adalah untuk mengetahui preferensi Generasi Y dalam memilih hunian, serta mengidentifikasi faktor-faktor apa saja yang menjadi acuan Generasi Y dalam memilih hunian, dengan begitu pembangunan hunian yang dilakukan tepat sasaran.

Diagram 1. Batasan Usia pada Penelitian

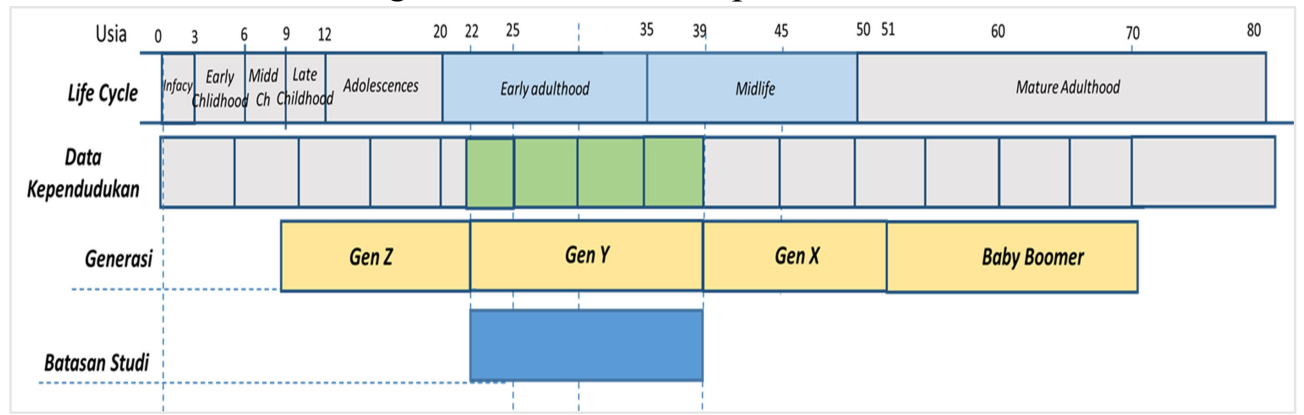

Sumber: Olahan Penulis, 2016

Batasan wilayah pada penelitian ini adalah Jakarta Barat, yang terbagi menjadi delapan kecamatan yaitu Kecamatan Grogol Petamburan, Kecamatan Kebon Jeruk, Kecamatan Palmerah, Kecamatan Kembangan,Kecamatan Cengkareng, Kecamatan Kalideres, Kecamatan Tambora, dan Kecamatan Taman Sari. Batasan substansial penelitian ini adalah Gen Y, yang pada tahun 2016 berusia 22-39 tahun. Kelompok usia ini memiliki presentase terbesar pada demografi penduduk di Jakarta Barat. Pada kelompok usia tersebut telah memasuki dua fase pada life cycle yaitu early adulthood dan fase midlife. Data populasi Gen Y di Jakarta Barat akan diperoleh dari BPS data kependudukan Jakarta Barat.

Di Amerika Serikat faktor yang disenangi Gen Y pada lingkungan huniannya adalah lingkungan yang stabil dan aman, lingkungan yang tenang, terdapat sekolah yang bagus, dekat dengan tempat kerja dan dengan waktu commute yang singkat, rumah yang menarik dan juga walkable neighborhood. (M. Leanne Lachman and Deborah L. Brett, 2015).

Aspek demografi dan sosial-ekonomi mempengaruhi preferensi pembelian hunian. Yuhui, T (2012) dari penelitiannya yang berjudul a Study of Housing Aspiration and Social Interaction of China's Generation $Y$ mengungkapkan bahwa dari sisi sosial-ekonomi ada tiga faktor yang mempengaruhi preferensi pemilihan hunian diantaranya pendapatan, tingkat pendidikan dan pekerjaan.

Pengaruh usia dalam memilih lokasi hunian dipengaruhi oleh Life Cycle dan ukuran keluarga juga komposisi keluarga serta status sosial. Bukan hanya usia yang menentukan pemilihan lokasi, namun sebenarnya perbedaan edukasi pada kelompok usia yang sama, pekerjaan, dan tingkat konsumsi. (Moos, Markus, dkk., 2015)

Pemilihan hunian dewasa muda dipengaruhi oleh kondisi ekonomi dan pasar perumahan. Hal ini sangat berkaitan dengan affordability mereka pada masa tertentu. Preferensi dewasa muda (Gen Y) dalam memilih hunian sangat penting karena usia mereka yang memasuki pasar hunian yang nantinya akan memberi pengaruh kepada tren yang akan terjadi. (Moos, Markus, dkk., 2015).

Gen Y sangat terkait dengan lifestyle yang karena adanya pengaruh teknologi digital yang berkembang pesat dan mempengaruhi karakteristik mereka. Menurut Rapoport (1980), gaya hidup (lifestyle) mempengaruhi preferensi pemilihan lokasi hunian yang dibagi menjadi empat, yaitu consumption oriented yang berhubungan dengan kenyamanan hidup dan memilih hunian pada pusat kota karena fasilitas yang lengkap; social prestige oriented yang lebih berhubungan 
dengan komunitas umumnya memilih daerah suburban; family oriented mengutamakan kepentingan anak-anak dan memilih hunian dengan halaman luas dan ketersediaan fasilitas untuk keluarga; dan community oriented merupakan pemukiman dengan jenis etnis tertentu atau pekerjaan tertentu.

\section{METODE PENELITIAN}

Metode yang digunakan dalam penelitian untuk mendapatkan data adalah kuantitatif deskriptif. Prosedur ini menghasilkan temuan yang diperoleh dari data-data yang dikumpulkan dengan menggunakan kuesioner dan penyebarannya menggunakan cara online. Penyebaran kuesioner dilakukan pada bulan November 2016.

Variabel yang terlibat dalam penelitian ini adalah variable terikat/ dependent dan variable bebas/ independent. Variable terikat yaitu Gen Y dan life cycle. Life cycle yang akan dibahas terbagi menjadi dua yaitu early adulthood dan midlife. Pengukuran akan menggunakan skala likert dan analisis korelasi menggunakan crosstab.

Gen Y di Jakarta Barat pada tahun 2016 berusia 22 tahun hingga 39 tahun memiliki jumlah penduduk 888.963 jiwa. Pengambilan sampel menggunakan Rumus Slovin, sehingga didapat jumlah sampel minimal 100 responden. Persebaran kuesioner secara online mendapatkan 220 responden, sedangkan ada 171 responden yang valid untuk penelitian. Agar penelitian ini dapat lebih mewakili Gen Y di Jakarta Barat digunakan 171 responden. Berikut ini realisasi responden penelitian berdasarkan enam kelompok usia.

Tabel 1. Realisasi Jumlah Responden Penelitian

\begin{tabular}{|c|c|c|c|}
\hline Fase & Kelompok usia & $\begin{array}{c}\text { Jumlah sampel } \\
\text { minimal }\end{array}$ & $\begin{array}{c}\text { Jumlah sample } \\
\text { penelitian }\end{array}$ \\
\hline \multirow{4}{*}{ 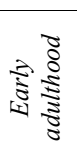 } & $22-24$ & 16 & 38 \\
\hline & $25-27$ & 18 & 34 \\
\hline & $28-30$ & 17 & 24 \\
\hline & $31-34$ & 23 & 23 \\
\hline \multirow{3}{*}{ 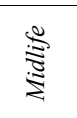 } & $35-37$ & 15 & 24 \\
\hline & $38-39$ & 10 & 28 \\
\hline & Jumlah & 100 & 171 \\
\hline
\end{tabular}

Sumber: Olahan Penulis, 2016

Sampel penelitian dibagi menjadi enam kelompok usia berdasarkan dua fase kehidupan yaitu early adulthood dan midlife. Perhitungan jumlah sample berdasarkan kelompok usia menggunakan teknik stratified proportionate random sampling / random proporsional berlapis (Gulo, 2002).

\section{HASIL DAN PEMBAHASAN}

Pada penelitian ini, Gen Y akan dibagi menjadi enam kelompok usia yaitu kelompok usia 22-24 tahun, usia 25-27 tahun, usia 28-30 tahun, usia 31-34 tahun, usia 35-37 tahun, dan usia 38-39 tahun.Jika dilihat dari fase kehidupan,Gen Y termasuk pada dua fase kehidupan dari duabelas fase kehidupan (Amstrong, 2008) yaitu earlyadulthood dan midlife. Fase earlyadulthood adalah fase dimana seseorang mulai mencapai tahap dewasa muda yang sedang membangun dan membina keluarga. Kelompok usia yang termasuk pada fase ini adalah usia 22-24 tahun, usia 2527 tahun, usia 28-30 tahun dan usia 31-34 tahun. Pada fase midlife, seseorang mulai mencapai suatu kestabilan. Gen Y yang termasuk dalam fase ini adalah kelompok usia 35-37 tahun dan usia 38-39 tahun. Penelitian ini hanya dapat mewakili Gen Y di Jakarta Barat karena adanya perbedaan karakteristik Gen Y pada masing-masing wilayah geografi. 


\section{Profil Gen Y di Jakarta Barat}

Untuk mengetahui Profil Gen Y di Jakarta Barat, dapat melihat analisis korelasi dengan menggunakan crosstab seperti pada tabel dibawah ini.

Tabel 2. Gambaran Umum Profil Gen Y di Jakarta Barat

\begin{tabular}{|c|c|c|c|c|c|c|c|c|c|}
\hline \multirow{3}{*}{ No } & \multirow{3}{*}{ Faktor } & \multirow{3}{*}{ Keterangan } & \multicolumn{6}{|c|}{ Usia } & \multirow{3}{*}{$\begin{array}{c}\text { Total } \\
\text { (Gen Y } \\
\text { keseluruhan) }\end{array}$} \\
\hline & & & \multicolumn{4}{|c|}{ Early adulthood } & \multicolumn{2}{|c|}{ Midlife } & \\
\hline & & & $22-24$ & $25-27$ & 28-30 & $31-34$ & $35-37$ & 38-39 & \\
\hline \multirow{2}{*}{1} & \multirow{2}{*}{ Jenis Kelamin } & Pria & $47.4 \%$ & $61.8 \%$ & $45.8 \%$ & $43.5 \%$ & $50.0 \%$ & $71.4 \%$ & $53.8 \%$ \\
\hline & & Wanita & $52.6 \%$ & $38.2 \%$ & $54.2 \%$ & $56.5 \%$ & $50.0 \%$ & $28.6 \%$ & $46.2 \%$ \\
\hline \multirow{3}{*}{2} & & SMA & $18.4 \%$ & $5.9 \%$ & $8.3 \%$ & $4.3 \%$ & $25.0 \%$ & $10.7 \%$ & $12.3 \%$ \\
\hline & Pendidikan terakhir & S1 & $76.3 \%$ & $79.4 \%$ & $66.7 \%$ & $47.8 \%$ & $62.5 \%$ & $78.6 \%$ & $70.2 \%$ \\
\hline & & $\mathrm{S} 2$ & $5.3 \%$ & $14.7 \%$ & $25.0 \%$ & $47.8 \%$ & $12.5 \%$ & $10.7 \%$ & $17.5 \%$ \\
\hline \multirow{3}{*}{3} & \multirow{3}{*}{ Status pernikahan } & Belum Menikah & $94.7 \%$ & $76.5 \%$ & $50.0 \%$ & $26.1 \%$ & $29.2 \%$ & $17.9 \%$ & $53.8 \%$ \\
\hline & & Menikah & $2.6 \%$ & $23.5 \%$ & $50.0 \%$ & $73.9 \%$ & $58.3 \%$ & $60.7 \%$ & $40.4 \%$ \\
\hline & & Bercerai & $2.6 \%$ & $0.0 \%$ & $0.0 \%$ & $0.0 \%$ & $12.5 \%$ & $21.4 \%$ & $5.8 \%$ \\
\hline \multirow{4}{*}{4} & \multirow{4}{*}{ Jumlah anak } & 0 & $100.0 \%$ & $91.2 \%$ & $70.8 \%$ & $39.1 \%$ & $37.5 \%$ & $32.1 \%$ & $66.1 \%$ \\
\hline & & 1 & $0.0 \%$ & $5.9 \%$ & $25.0 \%$ & $34.8 \%$ & $25.0 \%$ & $17.9 \%$ & $15.8 \%$ \\
\hline & & 2 & $0.0 \%$ & $2.9 \%$ & $4.2 \%$ & $17.4 \%$ & $33.3 \%$ & $46.4 \%$ & $15.8 \%$ \\
\hline & & lebih dari 2 & $0.0 \%$ & $0.0 \%$ & $0.0 \%$ & $8.7 \%$ & $4.2 \%$ & $3.6 \%$ & $2.3 \%$ \\
\hline \multirow{5}{*}{5} & \multirow{5}{*}{ Fase Keluarga } & Single & $94.7 \%$ & $73.5 \%$ & $50.0 \%$ & $26.1 \%$ & $37.5 \%$ & $35.7 \%$ & $57.3 \%$ \\
\hline & & $\begin{array}{l}\text { Pasangan tanpa } \\
\text { anak }\end{array}$ & $2.6 \%$ & $17.6 \%$ & $20.8 \%$ & $13.0 \%$ & $4.2 \%$ & $7.1 \%$ & $10.5 \%$ \\
\hline & & $\begin{array}{l}\text { Pasangan dengan } \\
\text { anak balita-TK }\end{array}$ & $0.0 \%$ & $8.8 \%$ & $29.2 \%$ & $52.2 \%$ & $20.8 \%$ & $10.7 \%$ & $17.5 \%$ \\
\hline & & $\begin{array}{l}\text { Pasangan dengan } \\
\text { anak SD }\end{array}$ & $2.6 \%$ & $0.0 \%$ & $0.0 \%$ & $8.7 \%$ & $33.3 \%$ & $21.4 \%$ & $9.9 \%$ \\
\hline & & $\begin{array}{l}\text { Pasangan dengan } \\
\text { anak SMP }\end{array}$ & $0.0 \%$ & $0.0 \%$ & $0.0 \%$ & $0.0 \%$ & $4.2 \%$ & $25.0 \%$ & $4.7 \%$ \\
\hline
\end{tabular}

Sumber: Olahan Penulis, 2016

Gen Y di Jakarta Barat mayoritas memiliki pendidikan terakhir S1 dan sebagian besar dari Gen Y sudah bekerja full time.

Pada fase early adulthood, Gen Y kelompok usia 22-24 tahun sebagian besar belum menikah. Kecenderungan Gen Y sudah menikah dimulai pada kelompok usia 28-30 tahun. Kepemilikan anak dimulai pada kelompok usia 31-34 tahun. Pada kelompok usia 30-34 status pernikahan yang paling banyak adalah yang sudah menikah. Pada fase midlife kelompok uisa 35-37 dan 3839 sebagian besar telah menikah dan memiliki anak balita-TK atau anak SD.

Dari segi life style (gaya hidup), Gen Y di Jakarta Barat pada umumnya memiliki kendaraan bermotor yaitu mobil dan/atau motor namun mereka juga senang menggunakan transportasi online. Sebagian besar Gen Y di Jakarta Barat tidak memiliki hewan peliharaan. Dari seluruh kelompok usia Gen Y, ketersediaan internet merupakan hal yang sangat penting. Gen Y juga mulai mementingkan aspek lingkungan. Pada kelompok usia yang lebih muda, yaitu usia 22-24 tahun dan usia 25-27 tahun, ketersediaan taman dan daerah yang walkable menjadi aspek penting, namun tidak begitu pada kelompok usia 35-37 tahun dan usia 38-39 tahun.

Secara keseluruhan, Profil Gen Y di Jakarta Barat memiliki kesamaan dan kesesuaian dengan teori Gen Y and Housing (M. Leanne Lachman and Deborah L. Brett, 2015), yaitu sebagian besar dari Gen Y sudah tidak sepenuhnya dibiayai oleh orang tua, dan sebagian besar sudah tidak menerima bantuan dari orang tua lagi. Gen Y juga memiliki latar belakang pendidikan yang tinggi dan sudah bekerja full time. Selain itu, pada analisis juga diketahui bahwa kebutuhan internet menjadi kebutuhan yang sangat penting bagi Gen Y. Perbedaan karakteristik Gen Y di 
Jakarta Barat dengan teori adalah Gen Y di Jakarta Barat menikah dan memiliki anak pada usia 28-30 tahun, sedangkan pada teori menjelaskan Gen Y menikah dan memiliki anak setelah usia 30 tahun. Namun secara keseluruhan, terjadi kesamaan antara karakteristik Gen Y di Jakarta Barat dengan yang dijelasikan pada teori.

\section{Profil Hunian dan Kondisi Hunian Gen Y di Jakarta Barat}

Jenis hunian di Indonesia (Fricylia, 2015) terdiri dari rumah tapak, town house, cluster, apartemen, kondotel, rumah susun, ruko/rukan, indekost dan kontrakan. Dari jenis hunian tersebut, pada penelitian ini jenis hunian dibagi menjadi dari landed housesyang terdiri dari rumah tapak, cluster, townhouse, kost, dan juga apartemen yang terdiri dari apartemen, rusun dan condominium.Profil hunian Gen Y di Jakarta dibagi menjadi empat bagian, yaitu Gen Y yang masih tinggal dengan orang tua, Gen $\mathrm{Y}$ yang menyewa ruang/kost, Gen $\mathrm{Y}$ yang menyewa hunian dan Gen Y yang membeli hunian. Untuk mengetahui profil hunian Gen Y di Jakarta Barat berdasarkan enam kelompok usia dapat melihat analisis korelasi dengan menggunakan crosstab pada tabel dibawah ini.

Tabel 3. Profil Hunian Gen Y di Jakarta Barat

\begin{tabular}{|c|c|c|c|c|c|c|c|}
\hline \multirow{3}{*}{ Profil Hunian } & \multicolumn{6}{|c|}{ Usia } & \multirow{3}{*}{ Total } \\
\hline & \multicolumn{4}{|c|}{ Early adulthood } & \multicolumn{2}{|c|}{ Midlife } & \\
\hline & $22-24$ & $25-27$ & $28-30$ & 31-34 & $35-37$ & 38-39 & \\
\hline Membeli & $13.20 \%$ & $8.80 \%$ & $16.70 \%$ & $43.50 \%$ & $45.80 \%$ & $64.30 \%$ & $29.80 \%$ \\
\hline Menyewa & $15.80 \%$ & $5.90 \%$ & $16.70 \%$ & $17.40 \%$ & $16.70 \%$ & $10.70 \%$ & $13.50 \%$ \\
\hline Kost & $13.20 \%$ & $5.90 \%$ & $25.00 \%$ & $8.70 \%$ & $4.20 \%$ & $7.10 \%$ & $10.50 \%$ \\
\hline Tinggal dgn ortu & $57.90 \%$ & $79.40 \%$ & $41.70 \%$ & $30.40 \%$ & $33.30 \%$ & $17.90 \%$ & $46.20 \%$ \\
\hline
\end{tabular}

Sumber: Olahan Penulis, 2016

Sebagian besar Gen Y di Jakarta Barat masih tinggal dengan orang tua karena mereka merasa senang berada di dekat keluarga, kelompok usia yang paling banyak masih tinggal dengan orang tua adalah kelompok usia 22-24 tahun. Hal berhubungan dengan mereka yang masih sekolah atau baru memasuki dunia kerja. Gen Y baru akan pindah hunian saat mereka menikah dan pindah bersama pasangan mereka. Walaupun tinggal dengan orang tua, Gen Y memberikan kontribusi finansial kepada orang tuanya.

Gen Y yang paling banyak menyewa kost adalah pada kelompok usia 28-30 dan 22-24 tahun. Kelompok usia 22-24 tahun memilih unit dengan luas kurang dari $12 \mathrm{~m}^{2}$, sedangkan pada kelompok usia 28-30 tahun yang diminati adalah dengan luas $12 \mathrm{~m}^{2}-20 \mathrm{~m}^{2}$.

Gen Y yang paling banyak membeli hunian adalah pada kelompok usia 38-39 tahun dan usia 3537 tahun. Jenis hunian yang paling diminati Gen Y adalah membeli rumah tapak dengan luas lahan $60 \mathrm{~m}^{2}-100 \mathrm{~m}^{2}$ dan luas bangunan $150 \mathrm{~m}^{2}-200 \mathrm{~m}^{2}$. Jumlah kamar pada rumah tapak mereka sebanyak 3 kamar. Gen Y yang menyewa apartemen memilih menyewa unit dengan 2 kamar dengan luas unit 40-55 $\mathrm{m}^{2}$.

Gen Y yang paling banyak menyewa hunian adalah pada kelompok usia 22-24 tahun dan usia 28-30 tahun. Pada kelompok usia 22-24 tahun biaya sewa sepenuhnya dibiayai oleh orang tua, jenis yang diminati adalah apartemen dengan 1 kamar tidur dan luas unit $25 \mathrm{~m}^{2}-40 \mathrm{~m}^{2}$. Pada kelompok usia 28-30 tahun, jenis hunian yang diminati seimbang antara rumah tapak dengan apartemen. Pada rumah tapak luas tanah yang diminati $60-150 \mathrm{~m}^{2}$ dengan luas bangunan 150 $200 \mathrm{~m}^{2}$.

Secara keseluruhan, profil hunian Gen Y di Jakarta Barat tidak sesuai dengan profil hunian Gen Y pada teori. Gen Y di Jakarta Barat mayoritas masih tinggal dengan orang tua, bukan karena 
terpaksa, tapi karena mereka merasa senang dan nyaman berada di dekat keluarga. Walaupun tingal dengan orang tua, mereka juga memberikan bantuan finansial kepada orang tua mereka. Berbeda dengan teoriGen $Y$ and Housing (M. Leanne Lachman and Deborah L. Brett, 2015) yang mengatakan bahwa Gen Y sebagian besar telah pindah dari rumah orang tua dan menyewa hunian. Di teori juga dijelaskan bahwa Gen Y yang masih tinggal dengan orang tua sebenarnya telah pindah namun kembali lagi karena mereka tidak mampu hidup sendiri atau kembali ke sekolah. Gen Y di Jakarta Barat nyaman dengan keluarganya, dan baru akan pergi dari rumah orang tua saat mereka menikah dan pindah bersama pasangan.

\section{Harapan Gen Y terhadap Hunian 5 Tahun Mendatang}

Pada tahun 2016, usia Gen Y adalah 22 tahun hingga 39 tahun. Pada 5 tahun mendatang usia Gen Y bertambah menjadi 27 tahun hingga 44 tahun. Seiring dengan perubahan usia terjadi juga perubahan fase kehidupan, perubahan jumlah pendapatan dan pengeluaran.

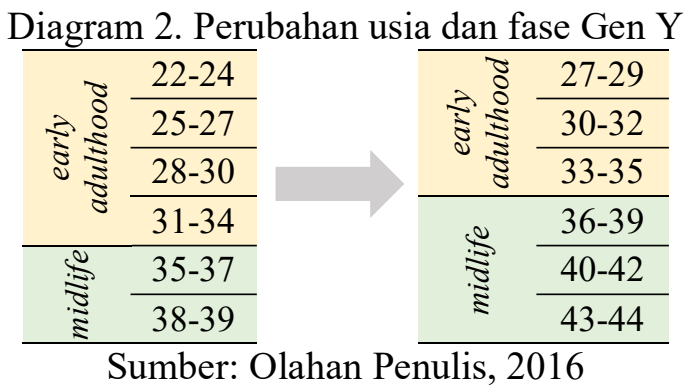

Gen Y secara keseluruhan pada 5 tahun mendatang menginginkan hunian landed houses dengann tipe rumah tapak dan juga cluster dengan kepemilikan membeli hunian. Jumlah kamar yang mereka inginkan adalah 3 kamar tidur. Namun keterbatasan lahan di Jakarta Baratdan keterbatasan kemampuan Gen Y tidak memungkinkan hal tersebut, Gen $\mathrm{Y}$ dapat mempertimbangkan untuk menyewa hunian dan tinggal di apartemen.

Lokasi hunian yang mereka inginkan adalah di Jakarta Barat yaitu Grogol Petamburan dan Kebon Jeruk. Dan ada keinginan untuk pindah ke suburban yaitu Serpong dan Tangerang.

Gen Y menginginkan kepemilikan hunian membeli hunian landed houses, dan juga berharap tidak mendapat bantuan dari orang tuanya. Namun, dari analisis yang telah dilakukan ditemukan bahwa Gen Y pada lima tahun mendatang baik pada fase early adulthood maupun fase midlife tidak mampu membeli/memiliki hunian sendiri tanpa bantuan dari orang tua/keluarga mereka. Sistem pembayaran yang paling diminati adalah KPA/KPR, dengan DP bantuan dari orang tua, baik seluruhnya ataupun sebagian dan cicilan yang dapat dibayar oleh Gen Y sendiri.

Terjadi ketidak-sesuaian keinginan Gen Y 5 tahun mendatang terhadap teori Gen Y and Housing (M. Leanne Lachman and Deborah L. Brett, 2015), Gen Y di Jakarta Barat secara keseluruhan menginginkan hunian landed houses, dengan kepemilikian membeli. Sedangkan pada teori tersebut dijeaskan karakter Gen Y yang bebas menyukai apartemen dengan kepemilikan sewa sehingga bersifat lebih fleksibel terhadap tempat tinggal. Gen Y di Jakarta Barat dalam memiliki keinginannya selain dari karakteristik diri, mereka dipengaruhi oleh kebudayaan, subkebudayaan, dan juga keluarga. Gen Y di Jakarta Barat sudah terbiasa tinggal dengan orang tuanya di landed houses mereka juga merasa nyaman dan senang tinggal dengan orang tuanya. Hal ini menjadi salah satu alasan Gen Y masih ingin tinggal di landed house. Selain itu, dalam memilih hunian lima tahun mendatang, Gen Y sangat dipengaruhi oleh lokasi tempat tinggal orang tua/ keluarganya, sehingga banyak dari mereka yang masih ingin tinggal di kecamatan 
mereka saat ini dengan alasan ingin berada dekat dengan orang tuanya, orang tua juga merasa senang jika anaknya tinggal dekat dengan mereka.

\section{KESIMPULAN}

Gen Y di Jakarta Barat sudah memiliki pendidikan yang cukup tinggi yaitu S1 dan mayoritas sudah bekerja full time, mereka mulai menikah pada kelompok usia 28-30 tahun. Dari segi life style, Gen Y senang dengan internet, mereka juga memiliki kecenderungan untuk menggunakan transportasi online saat bepergian. Dari sisi lain, Gen Y juga mementingkan lingkungan, mereka menyukai daerah yang walkable dan ketersediaan taman sangat penting.

Kondisi hunian Gen Y di Jakarta Barat saat ini didominasi oleh Gen Y yang masih tinggal di hunian orang tuanya. Gen Y merasa senang dekat dengan keluarga dan orang tua, mereka akan pindah hunian saat mereka telah menikah dan pindah bersama pasangan mereka. Berkaitan dengan hal tersebut, Gen Y pada fase midlife yang mayoritas telah menikah memiliki profil membeli hunian yang tinggi jika dibandingkan dengan jenis profil hunian lainnya.

Pada lima tahun mendatang, Gen Y di Jakarta Barat memiliki preferensi untuk membeli hunian dengan jenis rumah tapak dan cluster. Lokasi yang menjadi preferensi Gen Y di Jakarta Barat dengan presentase paling tinggi adalah di Kecamatan Grogol Petamburan dan di Kecamatan Kebon Jeruk. Ada juga kecenderungan Gen Y untuk pindah ke daerah suburban yaitu ke Serpomg dan Tangerang. Keterbatasan lahan di Jakarta Barat dan harga lahan yang semakin mahal tidak memungkinkan Gen Y untuk tetap tinggal di landed houses, Gen Y dapat mempertimbangkan kepemilikan sewa, dengan begitu masih dapat tinggal di lokasi dan tipe hunian yang diinginkan, namun uang yang dikeluarkan dapat lebih terjangkau.

Pada pengembangan landed houses, developer dapat membuat unit rumah dengan luas lahan yang lebih kecil pada suatu cluster, atau bisa juga dikembangkan bangunan apartemen dengan skala yang lebih kecil. sehingga harga yang dipasarkan dapat lebih terjangkau bagi Gen Y. Hal ini berkaitan dengan keinginan Gen Y dan juga kemampuannya dalam memiliki hunian.

Gen Y pada lima tahun mendatang masih membutuhkan bantuan dari orang tua dalam membeli hunian. Cara pembayaran hunian yang diminati adalah pembayaran dengan sistem KPA/KPR. Gen Y akan menerima bantuan dari orang tua berupa DP sebagian atau bahkan seluruhnya. Untuk cicilan, Gen Y dapat membayar sendiri dari selisih pendapatan dan pengeluaran mereka.

Ketersediaan fasilitas yang sangat penting bagi Gen $\mathrm{Y}$ dalam tinggal di apartemen adalah ketersediaan fasilitas laundry dan fasilitas penitipan anak. Hal ini berkaitan dengan unit apartemen yang tersedia tidak memiliki area cuci dan area untuk asisten rumah tangga. Gen Y yang sudah memiliki anak dan bekerja tidak memungkinkan untuk memiliki asisten rumah tangga yang menginap dengan begitu ketersediaan fasilitas penitipan anak menjadi penting. Selain itu, fasilitas penitipan anak dapat lebih terjamin untuk keamanan anak mereka.

Dalam mencari hunian, Gen Y cenderung lebih mendengarkan rekomendasi dari teman dan keluarganya. Selain itu, Gen Y juga lebih senang menggunakan internet. Dalam melakukan promosi, tim marketing harus dapat menggunakan strategi world of mouth yang baik. Selain itu, dalam promosi lebih baik menggunakan website dan juga online, seperti rumah.com, rumah123.com, dan rumahdijual.com karena Gen Y cenderung lebih memilih mencari secara online dan kurang tertarik dengan media cetak.

Gen Y perlu mempelajari financial management untuk pembiayaan huniannya di masa mendatang. Selain itu, mereka juga harus berusaha untuk memiliki pendapatan yang cukup besar 
untuk memenuhi ketentuan bank dalam mengajukan KPA/KPR. Berkaitan dengan keterbatasan lahan di Jakarta Barat dan harga lahan yang semakin tinggi, Gen Y perlu dapat mempersiapkan diri untuk tinggal di apartemen karena harga jual yang lebih terjangkau dan juga lokasi yang dapat disesuaikan dengan preferensi mereka yang ingin tetap tinggal di Jakarta Barat.

\section{UCAPAN TERIMA KASIH (Acknowledgement)}

Penulis menyampaikan ucapan terima kasih kepada Bapak Suryono Herlambang, S.T., M.Sc. dan Bapak Ir. Hari Ganie, M.M, selaku dosen pembimbing yang telah memberikan bimbingan, bantuan, dan arahan kepada penulis.

\section{DAFTAR PUSTAKA}

Amstrong, T. (2008 ). The Human Odyssey: Navigating the Twelve Stage of Life. New York: Sterling.

Carey Kathleen, d. (2014). The Macro View on Micro Units. Washington D.C. : Urban Land Institute.

Florida, R. (2008). Who's Your City? Canada: Random House.

Fricylia, P. (2015, oktober 4). Jenis Hunian Yang Dikenal di Indonesia. Retrieved from urbanindo website: http://urbanindo.com/2015/10/jenis-jenis-hunian-yang-dikenal-diindonesia/

Globe, F. G. (1987). Psiokologi Humanistik Abraham Maslow. Kanisius.

Gulo, W. (2002). Metodologi Penelitian . Jakarta: Gramedia Widiasarana Indonesia.

Jansen,STJ, dkk. . (2011). The Measurement and Analysis of Housing Preference. the Netherlands: Springer Science Business Media.

Kotler, Philip, dkk. (2003). Marketing Managemen An Asian Perspective. Third Edition. Singapore: Prentice Hall .

M. Leanne Lachman and Deborah L. Brett. (2011). Generation Y: America's New Housing Waves. Washington D.C. : Urban Land Institute.

M. Leanne Lachman and Deborah L. Brett. (2015). Gen Y and Housing: What They Want and Where They Want It. Washington D.C. : Urban Land Institute .

Marupang. (2011). Analisis Faktor-Faktor yang Mempengaruhi Konsumen terhadap Permintaan Perumahan . Jejak Vol. 4 No. 2, 126.

McCrindle, Mark and Emily Wolfinger . (2011). the ABC of XYZ: Undrestanding the Global Generation. Sydney: University of New South Wales Press Ltd.

Moos, M. (2014). "Generationed" space: Societal Restructuring and Young Adults' Changing Residential Location Patterns . The Canadian Geographer, 11-33.

Moos, M. (2015). From Generation to Youthification? The Increasing Importance of Young Age in Delineating High-Density Living. Urban Studies Journal , 1-18.

Moos, Markus, dkk. (2015). Youthification: New Kids on The Block. Waterloo: University of Waterloo School of Planning.

Rapoport, A. (1980). Human Aspects of Urban Form (Towards a Man-Environment Approach to Urban Form and Design). Oxford: Pergamon Press.

Ross, L. (2014). Residential Futures II: Thought Provoking Idea's on What Next for Multigenerational Housing and Intergenerational Communities. Washington D.C.: Urban Land Institute.

Solomon, M. (2009). Consumer Behavior Buying, Having, and Being. New Jersey: Person EducationInc. .

Yuhui, T. (2012). A Study of Housing Aspiration and Social Interactions of China's

Generation Y. Chong Qing: Department of Real Estate, National University of Singapore. 